\title{
In silico discovery of GPCRSs and GnRHRs as Novel SARS-CoV-2 binding receptors, the Scientific Breakthrough that could explain the observed High cortisol, Appetite loss, Ansomnia and Hypogonadism, as well as Hypothyroidism, Retinol deficiency and menstrual disturbances among SARS-COV-2 patients.
}

Mahmoud Ramadan Elkazzaz ( $\nabla$ mahmoudelkazzaz2051@gmail.com )

Department of chemistry and biochemistry, Faculty of Science, Damietta University, Egypt https://orcid.org/0000-0003-3703-520X

Amr Ahmed ( $\nabla$ drmedahmed@gmail.com)

Director of tuberculosis program Ghubera, public health department ,First health cluster ,Ministry of health, Riyadh, Saudia Arabia https://orcid.org/0000-0003-3477-236X

Ghareeb Alshuwaier ( $\nabla$ galshuwaier@ksu.edu.sa )

Professor of Sport Nutrition (Sport Nutritionist) Exercise Physiology Department, College of Sports Science and Physical Activity (King Saud University, Riyadh)

Israa M Shamkh

Chemo and Bioinformatics Lab, Bio Search Research Institution, BSRI. Giza , Egypt, Federal University of Alfenas, Brazil

\section{Yousry Esam-Eldin Abo-Amer}

Hepatology,Gastroenterology and Infectious Diseases Department, Mahala Hepatology Teaching Hospital, Egypt https://orcid.org/0000-0002-6136-8840

Tamer Haydara

Department of Internal Medicine, Faculty of Medicine, Kafrelsheikh University, Egypt

\section{Research Article}

Keywords: COVID-19, GPCRs, ACE2, GnRHR, Spike protein, Pulmonary edema and anosmia Posted Date: December 27th, 2021 
License: (c) (i) This work is licensed under a Creative Commons Attribution 4.0 International License. Read Full License 
In silico discovery of GPCRSs and GnRHRs as Novel SARS-CoV-2 binding receptors, the Scientific Breakthrough that could explain the observed High cortisol, Appetite loss, Ansomnia and Hypogonadism, as well as Hypothyroidism, Retinol deficiency and menstrual disturbances among SARS-COV-2 patients.

\section{Background}

COVID-19 is known to cause chemosensory dysfunction. A common symptoms of COVID-19 is a disorder in hormonal balance and olfactory function which may persist after recovery including COVID-19-related anosmia and hypogonadism. Hormonal problems such as Hypogonadism and Hypothyrodism are being observed in patients with Covid-19. Rise in cases of hormonal imbalance post COVID recovery is a cause for concern. Moreover, anosmia is a well-tolerated symptom of COVID19, but their aetiology isn't understood. The studies demonstrated that the new coronavirus could affect the central nervous system through the olfactory bulb or blood circulation. Furthermore, in addition to anosmia or hyposmia induction, as well as taste disorders, the virus may cause Appetite loss, High cortisol, Anxiety ,Retinol deficiency, Eye-ache, earache, Dizziness, Memory, Minstrual disturbances and hallucination. G-protein coupled receptors (GPCRSs) are well known to be expressed throughout the body, and they represent the genome's largest superfamily of signaling. It was showed that G-protein coupled receptors (GPCRS) and Gonadotropin-releasing hormone receptors (GnRHRs, a subtype of GPCRS), were expressed sufficiently in olfactory region and hypothalamus as well as thyroid gland and the human lung. It was found that GPCRs are responsible for diverse biological functions such as Appetite, Cortisol level, Smelling and Tasting regulation as well as Retinol transport and act as receptors of Thyroxin. Herein by using molecular docking and stimulation analysis, we succeeded to elucidate the direct neuroinvasive route of COVID-19 into the nasal epithelium and human brain cells which may lead to anosmia and hormonal imbalance mainly through the olfactory route by direct binding to G-protein coupled receptors (GPCRS). Furthermore, we strongly suspect that binding of COVID-19 to the expressed GPCRS in the lung is a main cause of ion changing disruption leading to pulmonary edema and failure . Moreover, we confirmed our results by investigating Gonadotropin-releasing hormone receptors (GnRHRs) as a novel binding receptor of COVID-19.

\section{Methodology}

In the current study, we used PatchDock server to conduct a docking study of the SARS-CoV-2 Spike protein with both of GnRHRs and GPCRSs protein. The structure of the crystal structure of the proteins were retrieved from RSCP 
(https://www.rcsb.org/ ) with accessions numbers (PDB ID $7 \mathrm{BR} 3$ and 6P9X respectively. we obtained the crystal structure of spike with accession number (PDB ID: 6VYB). The proteins are downloaded in the pdb format. The spike - receptor protein was investigated to determine the conservative residues of binding of Spike protein with the GnRHRs and GPCRS proteins in order to discover the ability of Spike to interact with GnRHR and GPCR receptors. We performed Molecular Dynamics (MD) Simulation to investigate the positional and conformational changes of the included proteins in relation to the binding site that provides insight into the binding stability. MD simulation of the complex was carried out with the GROMACS 4.5.4 package using the GROMOS96 43 a1 force field .

\section{Results}

This analysis of simulations molecular dynamics and molecular docking showed a high affinity between Spike protein and both of GnRHRs and GPCRSs . Results indicated that the spike binds to GNRHRS with binding energy $(-1424.7 \mathrm{k} . \mathrm{cal} / \mathrm{mol})$ and to GPCRS with binding energy $(-1451.8 \mathrm{k} . \mathrm{cal} / \mathrm{mol})$. The obtained results confirmed that the native model binds to GPCRS with the highest docking score of ( 1451.8) when compared to the other GNRHRS complexes, which have the lowest binding affinity, as evidenced by the docking score of (-1424.9). These results signifies better conjugation of GNRHRS to the binding pocket of the spike receptor in the RDB of the spike protein . Comparing the binding free energy of GPCRS to GNRHRS showed that the GNRHRS protein was found to bind to the vital residues in the RBD of the spike protein. But GPCRSs protein were found to bind to new RDB in other place in chain B of the spike. The molecular dynamics (MD) simulations study revealed significant stability of s pike protein with the GnRHRs and GPCRS separately up to $50 \mathrm{~ns}$.

\section{CONCLUSIONS}

The COVID-19 entry receptor, angiotensin-converting enzyme 2 (ACE2), is not expressed in the receptor of olfactory neurons, or its generation is limited to a minor fraction of these neurons. A change or disorder in hormonal balance and olfactory function is a common symptom of COVID-19 as well as Appetite loss and retinol deficiency, but its aetiology is unknown. SARS-CoV-2 was found to bind strongly and directly to both GPCRS and GnRHRs which expressed sufficiently in olfactory neurons. As a result, we confirm that COVID-19 could use these receptors especially GNRHRS as a direct neuroinvasive route into human brain cells, potentially leading to long-term neurological complications and hormonal imbalance in addition to Appetite loss and retinol deficiency via the olfactory route. Our findings may also shed a new light on the mechanism of pulmonary edema in COVID-19 patients. Therefore ,we propose that GPCRS and is involved in COVID-19 pathophysiology and can be exploited as a potential therapeutic target for COVID-19. 


\section{Introduction}

G-protein coupled receptors (GPCRSs) are well known to be expressed throughout the body, and they represent the genome's and are the largest and .largest superfamily of signalling proteins(1), the most diverse group of membrane receptors in eukaryotes. They are activated by a wide range of ligands, including light energy, lipids, sugars, peptides, and proteins $(2,3,4)$, which transport information from the outside environment into the cell in order to mediate the corresponding functional responses. When GPCRSs bind to ligands, their conformational changes trigger a cascade of biochemical reactions within the cell. These intracellular reactions control sensory functions like smell, taste, and vision, as well as a wide range of physiological processes like secretion, neurotransmission, metabolism, cellular differentiation, inflammation, and immune responses $(5,6,7,8)$. Almost $80 \%$ of COVID-19 infected patients experience significant symptoms which is neurological origin such as anosmia , unconsciousness ,dizziness, headaches, muscle tiredness and irritability. (9) A study showed that COVID-19-related anosmia has been linked to inflammation and viral persistence in the olfactory epithelium region, as well as infection of the brain in hamsters models (10). Although, previous research showed that COVID-19 enters the brain via an olfactory path from the nose toward brain(11,12,13,14). But, the COVID-19 entry receptor, angiotensinconverting enzyme 2 (ACE2), is not expressed in receptor of olfactory neurons, or its generation is limited to a minor fraction of these neurons $(15,16,17,18)$. Expression profiling of 100 GPCRSs demonstrates that most are expressed in multiple tissues and that individual tissues express multiple GPCRSs. Over 90\% of GPCRSs are expressed in the brain(52). GPCRSs expressed sufficiently in 
olfactory bulb (OB) and act as olfactory receptors(53) GPCRSs are signal receptors that respond to a wide range of stimuli. Chemosensory GPCRSs (csGPCRSs) are receptors for sensory signals from outside the body that are detected as odors, pheromones, or tastes $(54,55)$. Peptides, lipids, neurotransmitters, and nucleotides are all examples of endogenous signals that GPCRSs respond to $(56,57)$. These GPCRSs are involved in a variety of physiological processes, including neuronal excitability regulation, metabolism, reproduction, development, hormonal homeostasis, and behaviour. Two specific GPCRSs, A2B adenosine receptors and 2 adrenergic receptors, are primarily involved in CFTR regulation and are abundantly expressed in airways $(58,59)$. Under physiological conditions, the adenosine-CFTR regulation system is critical for mucosal airway surface protection (60) and alveolar surface layer(ASL) regulation (61). Viruses, on the other hand, are well known for their ability to not only exploit GPCRSs to enter host cells, but also to use their intracellularsignalling pathways for survival and replication (62). GPCRS induce Retinol-binding protein (RBP) and retinoid signaling indirectly via inducing both of follicle-stimulating hormone (FSH) and luteinizing hormone ( $\mathrm{LH})$ (67). It was showed that female patients with COVID- 19 had various extents of transient menstrual changes, mainly manifesting as prolonged cycles and decreased volume. A few patients also showed shortened or disordered menstrual cycles and increased volume, which were rarely observed in the control group. Younger women in Wuhan, China's outbreak experienced changes in their menstrual cycles while hospitalized for acute illness with COVID-19 infection(68). The most common change was having menstrual cycles that were 33 days or more apart (that occurred for 42 percent of the 237 women studied) (68). These longer cycles were much more common in sicker women who needed ventilators or intensive care(68). Women's reproduction can be suppressed by any acute illness, as we have known for eons. In a 1977 study, for example, menopausal women hospitalized with terminal illness had very low levels of luteinizing hormone (LH), so low that they were comparable to menstruating women's LH levels (typically 5-15). LH levels increased toward normal high menopausal levels as women were treated and recovered (in the 50-150 range) (69). The very sick women had similar, lower-than-expected LH levels. Weight loss, illnesses and emotional/social/psychological 
stress are well known to alter women's menstrual cycles. The brain (hypothalamus) has a protective role; it makes adaptations to protect women from pregnancy when under duress. Brain signals cause lower gonadotrophins (the two hormones called LH and follicle stimulating hormone $[\mathrm{FSH}]$ that are part of a complex coordinating system for women's reproduction. According to our findings COVID19 could bind to GPCRs and GNHRHs leading to disruption of different GPCRS and GNHRHs signaling resulting in existing symptoms and complications including Hormonal imbalance ( High cortisol, Hypognadism, Hyapothyrodism lymhopenia, Nuerogical disorders, Ineffective RIG-I pathway, Interferon inhibition, Hormonal imbalance, Thrombosis, and Smell .(and taste loss.

\section{Methodology}

\section{Molecular Docking}

\section{Dataset of the proteins}

In the current study we used PatchDock server to conduct a docking study of the SARS-CoV-2 Spike protein with both of GnRHRs and GPCRSsprotein.. The structure of the crystal structure of the proteins are retrieved from RSCP (https://www.rcsb.org/ ) with accessions numbers (PDB ID $7 \mathrm{BR}_{3}$ and $6 \mathrm{P} 9 \mathrm{X}$ respectively. we obtained the crystal structure of spike (PDB ID: 6VYB). The proteins are downloaded in the pdb format. The spike receptor protein was investigated to determine the conservative residues of binding of Spike protein with the GnRHRs and GPCRS proteins in order to discover the ability of Spike to interact with GnRHRs and GPCRSs and to explain the loss of smelling and taste as well as retinol deficiency, hormonal imbalance and lung edema if the spike protein of the virus are bind with GNRHRS and GPCRSs in a good binding affinity that declare the mechanism of the interaction which lead to lose of the smelling of the human . protein Docking study of each Spike - GNRHRS GPCRSs protein were carried out using PatchDock server, this uses molecular docking algorithm based on structure geometry. Firstly, we put the proteins (spike, GNRHRS and GPCRS) after we download it from RSCP we submit it on SAMSON software For pre-docking, all water molecules and ligands were removed while hydrogen atoms were added to the target proteins. In addition, the affinity minimization was performed. For Spike with all of them 
GPCRS and GNRHRS proteins to make docking between them to get know are the spike will bind to anther receptor GPCRS or GNRHRS .Secondly we submited the data into the server, spike as receptor (spike - receptor) and the ligand (GPCRS), at the first then (spike as a receptor) and the ligand (GNRHRS), in which both amino acid sequences and PDB structures are supported. Then, submitted into the server PatchDock program.

\section{PatchDock program}

We performed docking analysis using PatchDock program. This uses molecular docking algorithm based on structure geometry. The PatchDock algorithm divides the Connolly dot surface representation of the protein molecules into three classes, namely, convex, concave, and flat patches $(64,65)$. Then, complementary patches were matched to generate the candidate transformations. Each of the candidate transformation is additionally evaluated by a scoring function which considers both the atomic desolvation energy and geometric fit (66). Next, root mean square deviation (RMSD) clustering is applied to the candidate solutions to discard redundant solutions. The input parameters for the docking are the PDB coordinate file of the protein and ligand molecule. Three major steps are followed in the PatchDock analysis: (i) surface patch matching, (ii) molecular shape representation, and (iii) filtering and scoring.

\section{Molecular Dynamics Simulation}

MD simulation of the complex was carried out with the GROMACS 4.5.4 package using the GROMOS96 43 a1 force field. The lowest binding energy (most negative) docking conformation generated by AutoDock was taken as initial conformation for MD simulation. The topology parameters of proteins were created by using the Gromacs program. The complexes (spike - GNRHRS ) and (spike - GPCRS )was immersed in an octahedron box of simple point charge (SPC) water molecules. ( $336-267$ ) Na+ counter-ions were added by replacing water molecules to ensure the overall charge neutrality of the simulated system. (spike - GNRHRS ) and (spike - GPCRS ) complexes were energy-minimized initially by steepest descent 10,000 steps, followed by conjugate gradient method 10,000 steps. In 
order to equilibrate the system, the solute was subjected to positionrestrained dynamics simulation ( NPT) at $300 \mathrm{~K}$ for $300 \mathrm{ps.}$ Finally, the full system was subjected to MD production run at $300 \mathrm{~K}$ temperature and 1 bar pressure for $20000 \mathrm{ps}$. MD simulations were repeated thrice in order to verify the reproducibility of our study.

\section{Analysis of Molecular Dynamics Trajectory}

The trajectory files were analyzed by using g_rms, g_rmsf, and g_sas GROMACS utilities in order to obtain the root-mean-square deviation (RMSD), root-mean square fluctuation (RMSF), and solvent accessibility surface area (SASA). Numbers of distinct intermolecular hydrogen bonds formed during the simulation were calculated using g_h bond utility. The trajectory files of PCA were analyzed through the use of g_covar and g_anaeig of GROMACS utilities in order. The analysis of the secondary structure elements of the protein was performed using the program "do_dssp," which utilizes the DSSP program [54].

\section{Results and Discussion}

\section{Docking Analysis}

To investigate the binding of the spike with GPCRS and GNRHRS proteins, docking analysis was carried out with a specific GPCRS and GNRHRS proteins . Results indicated that the spike are bind to GNRHRS in (PHE 456- GLN 493 -GLY 496 -THR 500 - GLY 502 - LEU 455 -TYR 449 - LYS 417) which are the vital residues in the RDB of the Spike proteins which bind to GNRHRS by binding energy $-1424.7 \mathrm{k} . \mathrm{cal} / \mathrm{mol}$. GPCRS results indicated that Comparing the binding free energy of GPCRS to GNRHRS showed that the GNRHRS protein was found to bind to the vital residues in the RBD of the spike protein. But GPCRSs protein were found to bind to new RDB in other place in chain $B$ of the spike as showed in table 1.

\begin{tabular}{|l|l|l|l|}
\hline Proteins & PDB ID & $\begin{array}{l}\text { Binding } \\
\text { energy }\end{array}$ & $\begin{array}{l}\text { Protein binding } \\
\text { with RDB of spike }\end{array}$ \\
\hline
\end{tabular}




\begin{tabular}{|c|c|c|c|}
\hline $\begin{array}{l}\text { Spike } \\
\text { GNRHRS }\end{array}$ & $\begin{array}{l}\text { PDB ID spike : 6VYB } \\
\text { PDB ID GNRHRS:6P9X. }\end{array}$ & $x^{2}$ & $\begin{array}{l}\text { PHE } 456 \\
\text { GLN } 493 \\
\text { GLY } 496 \\
\text { THR } 500 \\
\text { GLY } 502 \\
\text { LEU } 455 \\
\text { TYR } 449 \\
\text { LYS } 417\end{array}$ \\
\hline $\begin{array}{l}\text { Spike } \\
\text { GPCRS }\end{array}$ & PDB ID GPCRSS: $7 \mathrm{BR}_{3}$ & -1451.8 & $\begin{array}{l}\text { TYR } 28 \\
\text { ASN30 } \\
\text { PHE } 33 \\
\text { THR } 33 \\
\text { PHE } 59 \\
\text { ASN } 61 \\
\text { ASN } 211 \\
\text { ASP } 215 \\
\text { PRO } 217 \\
\text { GLN } 218 \\
\text { GLY } 219 \\
\text { PHE } 220 \\
\text { LYS } 278 \\
\text { THR } 286 \\
\text { ASP } 287 \\
\text { LEU } 293\end{array}$ \\
\hline
\end{tabular}




\begin{tabular}{|l|l|l|}
\hline & & ASP 294 \\
PRO 259 \\
LEU 296 \\
SER 297 \\
LYS 300 \\
THR 602 \\
& ASN 603 \\
& THR 604 \\
& SER 605 \\
& ASN 606 \\
& GLU 607 \\
& VAL 608 \\
& ALA 609 \\
& VAL 610 \\
& CYS 617 \\
\hline
\end{tabular}

Table 1 displays the lowest calculated binding energy value of GPCRS and GNRHRS docked to the spike protein in RDB

The GPCRS and GNRHRS binding to spike protein RDB the table 1 show that the GNRHRS protein are bind to the vital residues. Comparing to the binding free energy of GPCRS which not bind to $\mathrm{RDB}$ but bind in other place in chain $\mathrm{B}$ of the spike protein the result show that the lowest binding is GNRHRS and the highest GPCRS ($1424.9,-1451.8)$ representatively Detailed analysis showed that the GPCRS acquired an altered mode of binding in spike protein . both of the GPCRS and GNRHRS complexes are showed in secondary structure in Figure 1, it is clear that in the native model of the spike and its binding to GNRHRS are take an alternative way to bind to 
spike protein like ACE2 .also and GPCRS are bind in deferent chain to get the effect of losing the smelling .
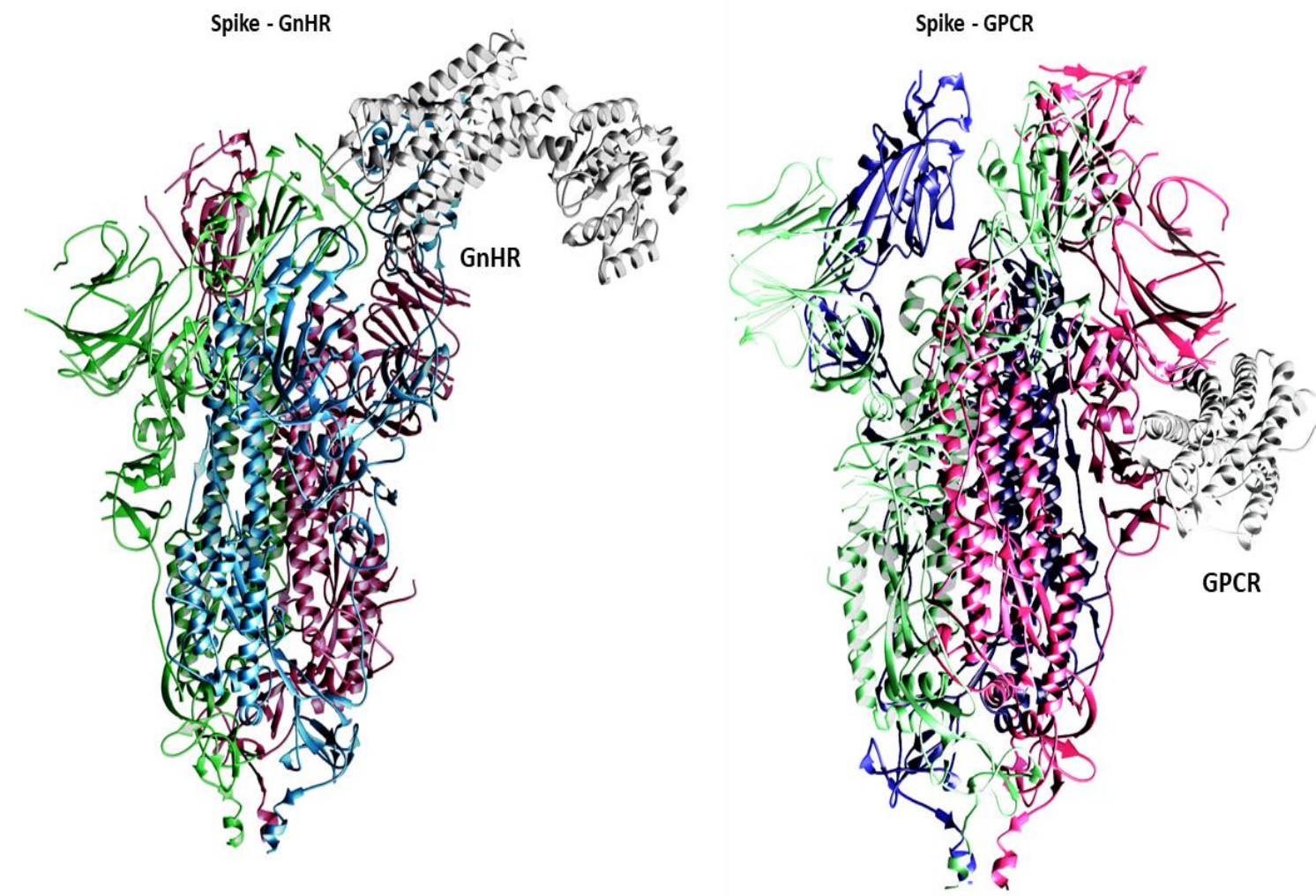

Figr 1. shows the spike protein with GNRHRS in the left side as see in the figer its bind like an ACE2 in the same binding energy in the right side spike protein binding with GPCRS 
Spike - GPCR
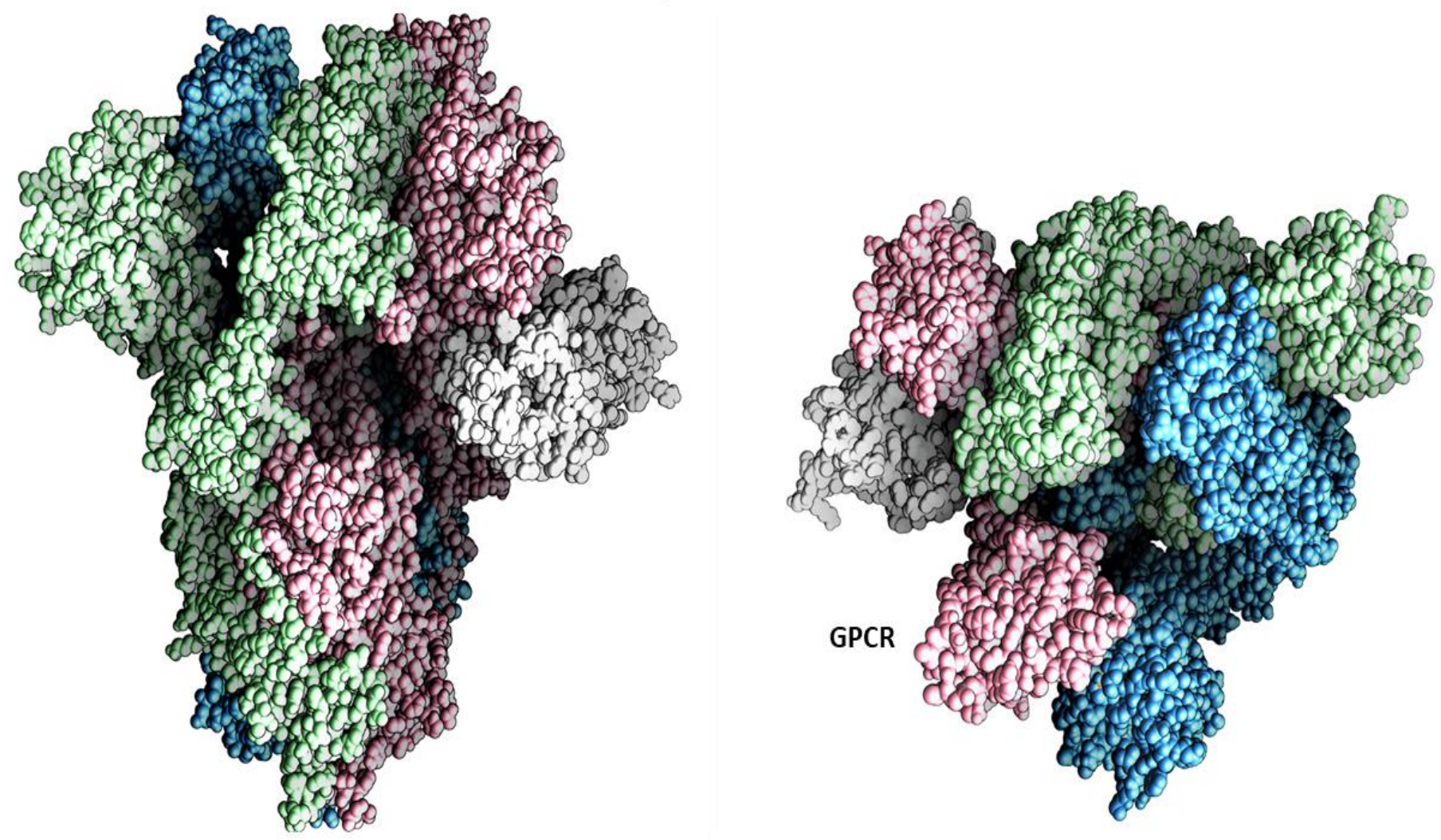

Figer 2 shows the binding of the spike protein which is in blue, green and rose which is the tree chains of the protein chain $A, B$ and $C$ which bind to the white part which is GPCRS as show its bind in alternative way to get the effect of losing smelling 


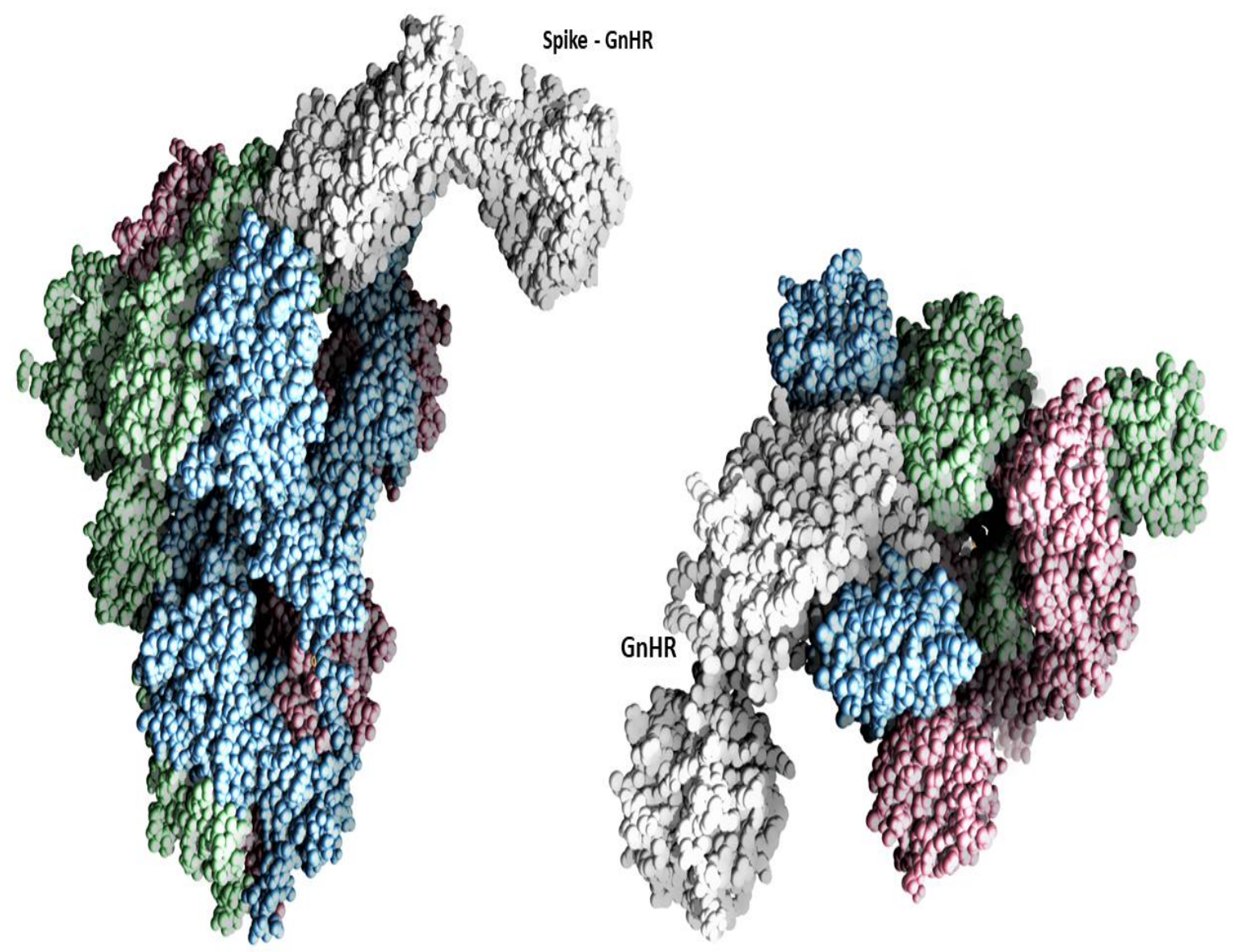

Figer 3 the binding of the spike protein which is in blue,green and rose which is the tree chains of the protein chain $A, B$ and $C$ which bind to the white part which is GNRHRS as show it binds in the RDB of spike protein so it is an alternative way to get the effect of losing smelling

Results were described before to optimize the Docking score of the native model of spike with GNRHRS and GPCRS. the calculated energy are done by using Patch Dock (Table 1). The obtained results confirmed that the native model binds to GPCRS with the highest docking score of -1451.8 when compared to the other GnRHRs complexes, which have the lowest binding affinity, as evidenced by the docking score of -1424.9.. These results signifies better conjugation of GNRHRS to the binding pocket of the spike receptor in the RDB of the spike protein . Comparing the binding free energy of GPCRS to GNRHRS showed that the GNRHRS protein was found to bind to the vital residues in the RBD of the spike protein. But GPCRSs protein were found to bind to RDB in other place in chain $B$ of the spike. 


\section{Simulation Study of (spike - GNRHRS) and (spike - GPCRS Complexes}

The results obtained from the above docking analysis provoked us to explore the dynamic behavior of (spike - GNRHRS ) and (spike GPCRS )Complexes. We analyzed the root mean square deviation (RMSD), root mean square fluctuation (RMSF), radius of gyration $(\mathrm{Rg})$, solvent accessible surface area (SASA), number of hydrogen bonds $(\mathrm{NH})$

$$
R M S F_{i}=\sqrt{\left.\left.\frac{1}{T} \sum_{t=1}^{T}<\left(r_{i}^{\prime}(t)\right)-r_{i}\left(t_{r e f}\right)\right)^{2}\right\rangle}
$$

The main purpose of the MD simulation studies was to investigate the positional and conformational changes of GNRHRS and GPCRS proteins in relation to the binding site of spike protein RDB that provides insight into the binding stability. MD revealed that GNHR could efficiently activate the biological pathway with changing the conformation in $\mathrm{c}$ terminal and $\mathrm{N}$ terminal but its effects on the middle of the protein in between $1000: 1500$ residues in RMSF plot

$$
R M S D_{x}=\sqrt{\left.\frac{1}{N} \sum_{j=1}^{N}\left(r_{j}^{\prime}\left(t_{x}\right)\right)-r_{i}\left(t_{\text {ref }}\right)\right)^{2}}
$$

in the binding site of spike protein as in figure 4 (spike - GNHR ) in addition to the MD simulation of GPCR are revealed that its efficiently activate the biological pathway with changing in the conformation in c terminal and the middle of the protein in between $500: 1000$ residues in the $\mathrm{C}$ terminal and from $1300: 1500$ in RMSF plot in the binding site of spike protein as in figure 4 (spike - GPCR). To evaluate the stabilities of (spike - GNHR ) and (spike - GPCR )Complexes, during the MD simulations, root mean square deviation (RMSD) where it is used to measure the average change in displacement of a selection of atoms for a particular frame with respect to a reference frame. It was calculated for all frames in the trajectory. The RMSD for frame $\mathrm{x}$ is for (spike - GNHR ) and (spike GPCR )Complexes was calculated with respect to the initial structures along (the 50 (ns)) trajectories (Fig. 4). The trajectories indicated for (spike - GNHR) and (spike - GPCR )the binding of the receptor on the active site after 50 ns in system with a mean RMSD 
value of (7.5 ns ,4.9 ns) representatively . In addition, the confirmation change of the (spike - GNHR ) protein between 1000 : 1500 in the system also proved the credibility of the docking results. Total energy of the most active conformation of the molecule was -1424.9 K.cal / mol . Also the confirmation change of the (spike GPCR) protein are affected in the $\mathrm{C}$ terminal and the middle so it is between $500: 1000$ residues in the $\mathrm{C}$ terminal and from $1300: 1500$ in the middle in the system also proved the credibility of the docking results and the binding between (spike - GPCR explore new binding site in spike protein .Total energy of the most active conformation of the molecule was $-1424.9 \mathrm{~K} . \mathrm{cal} / \mathrm{mol},-1451.8 \mathrm{~K} . \mathrm{cal} / \mathrm{mol}$ for (spike - GNHR ) and (spike - GPCR) representatively The temperature and pressure do not have any effect on the conformation of the structure. The hydrogen bonds formed between the protein and inhibitor after simulation were mostly concentrated in the activation loop region of the protein which is responsible for the catalytic machinery and substrate binding. This is explicitly understood from the above observation.
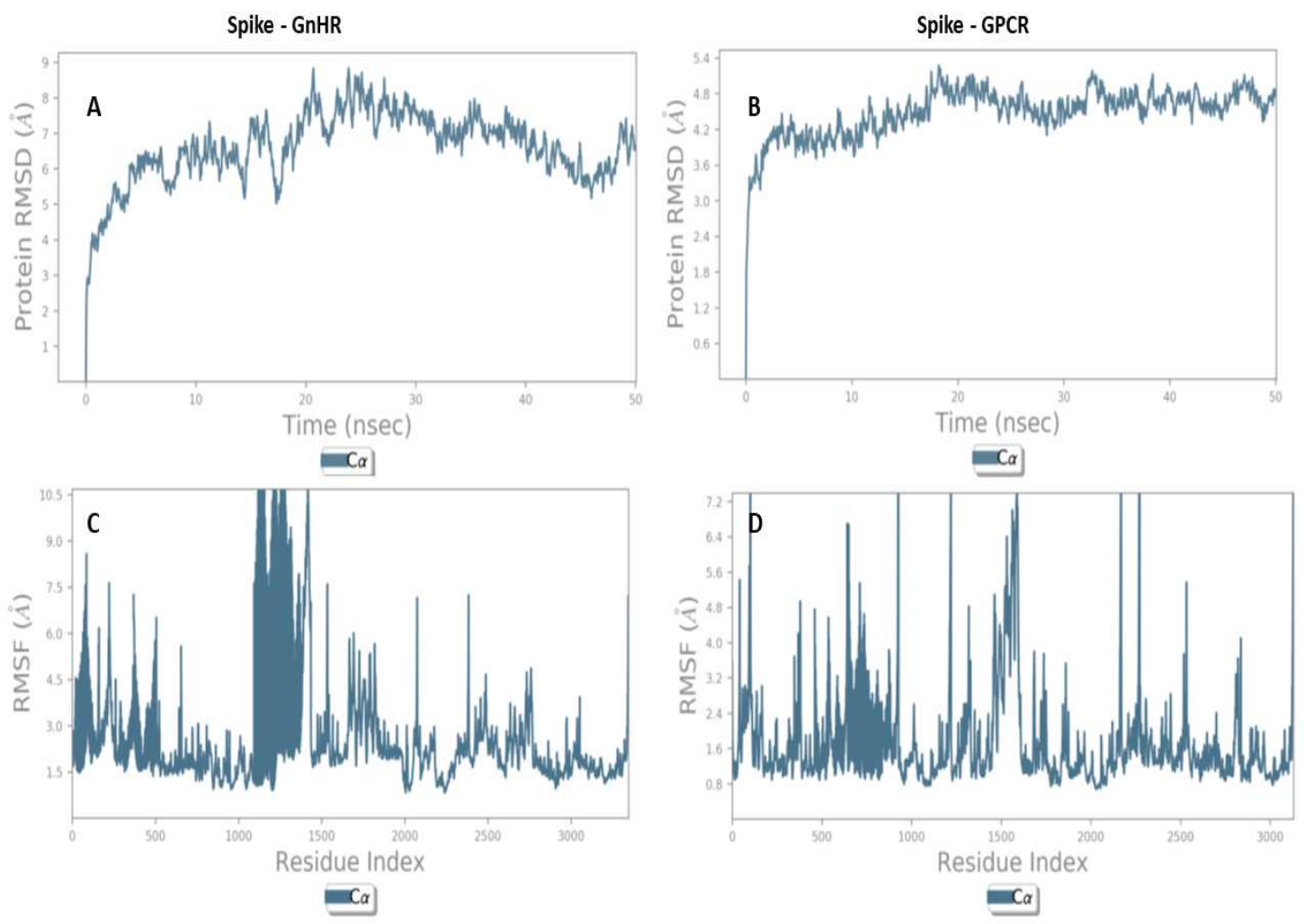

Figure 4. Root Mean Square Deviation (RMSD) as a function of simulated times for the complexes formed between SARS-CoV-2 Spike protein with GPCRSS and GNRHRS protein. The Root Mean Square Fluctuation (RMSF) is useful for characterizing local changes along the protein chain. Analysis of RMSD and RMSF of (spike - GNHR ) and (spike - GPCR) complexs at 30000 ps. (A,B) Time evolution of backbone RMSDs of the (spike - GNHR 
)structure. (C, D) RMSF of the carbon alpha over the entire simulation. The ordinate is RMSF (Ao), and the abscissa is residue.
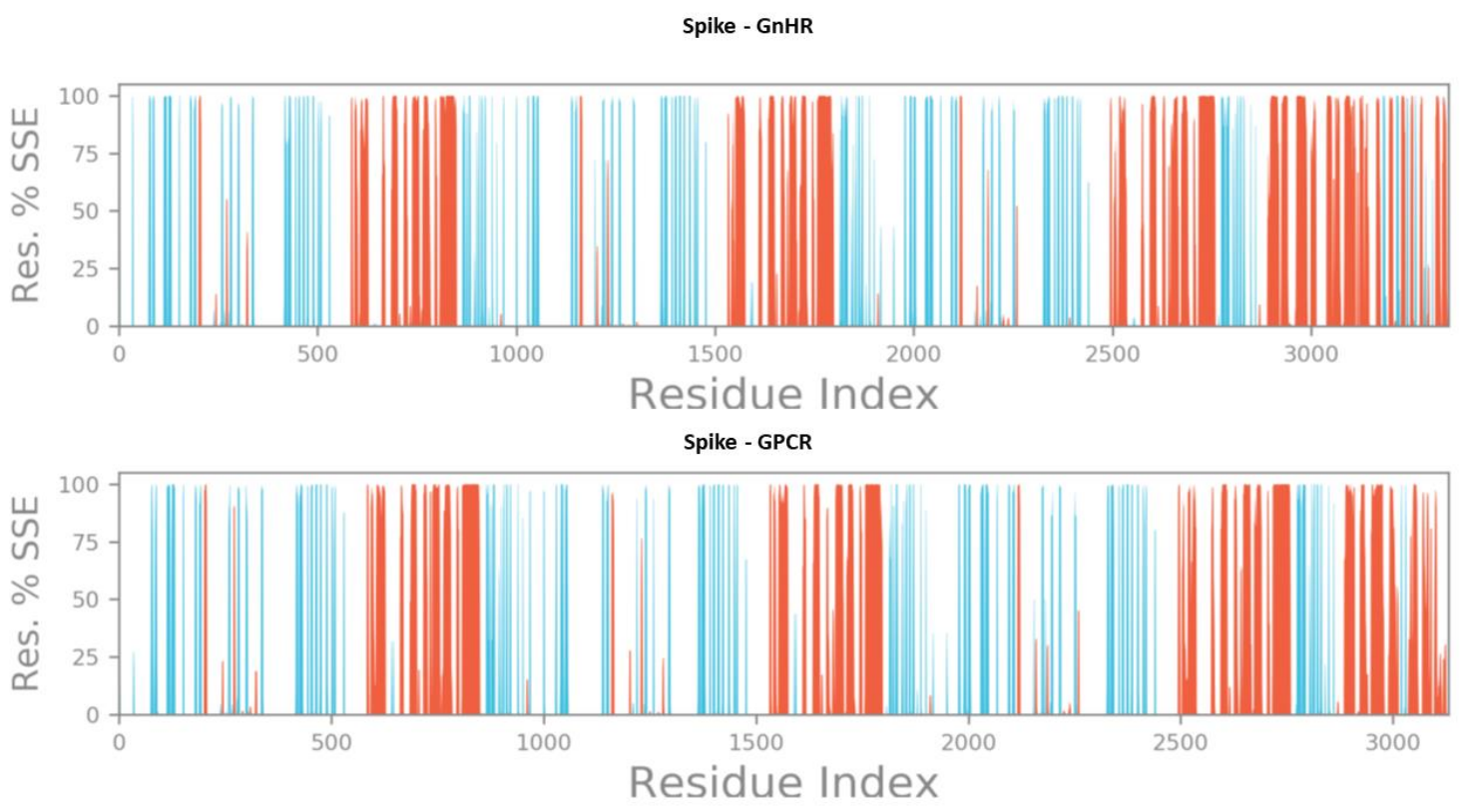

Figure 5. Protein secondary structure elements (SSE) like alpha-helices and betastrands For spike - GnHR and spike - GPCR are monitored throughout the simulation. The plot above reports SSE distribution by residue index throughout the protein structure. The plot below summarizes the SSE composition for each trajectory frame over the course of the simulation, and the plot at the bottom monitors each residue and its SSE assignment over time. The \% Helix , \% Strand and \% Total SSE are $(21.93,13.56,35.48)$ and $(20.25,13.79,34.04)$.
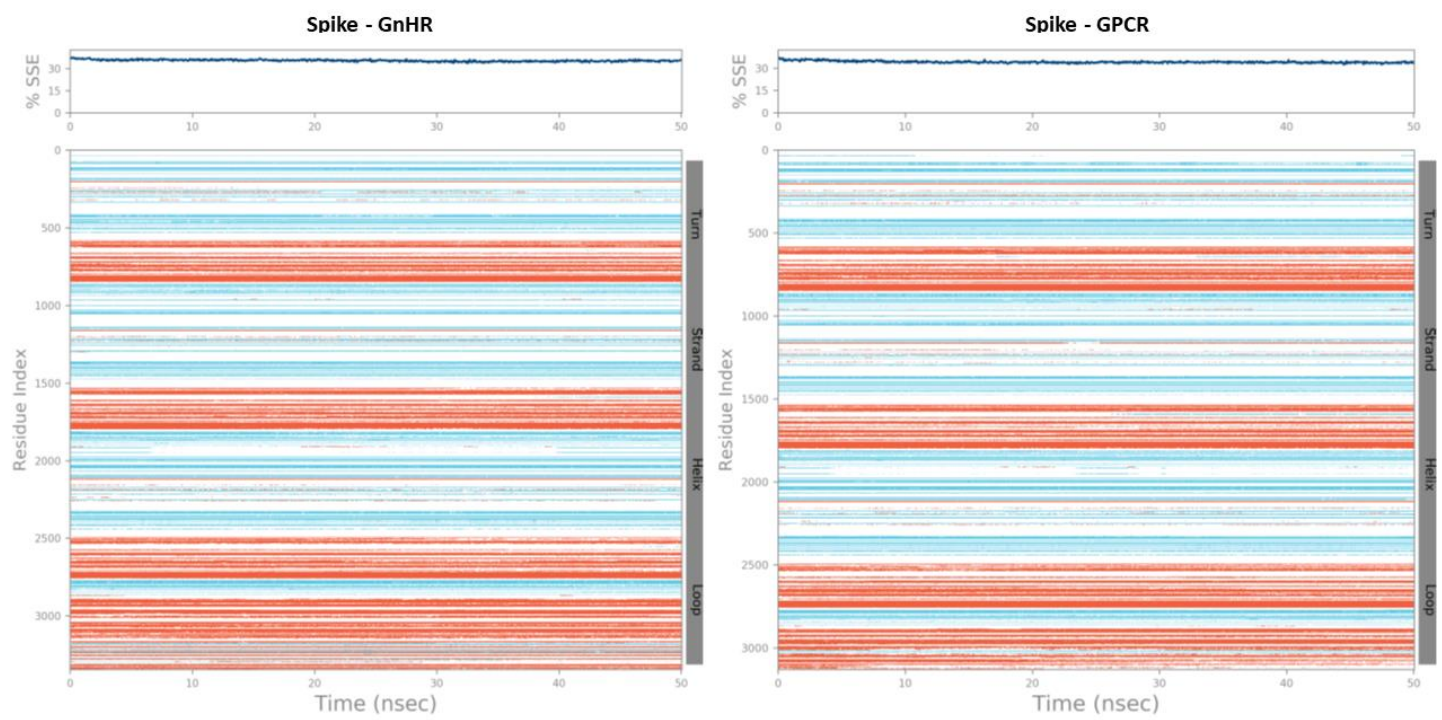
Figure6. The plot above reports SSE distribution by residue index throughout below summarizes the SSE the spike - GnHR and spike - GPCR structure. The plot composition for each trajectory frame over the course of the simulation where it monitors each residue and its SSE plot at the bottom done for $50 \mathrm{nsec}$, and the assignment where its $30 \%$ over time.

\section{Binding of COVID-19 to GNRHRS, a subtypes of GPCRSS could lead to smell losing and hypogonadism.}

The new coronavirus was found to have the ability to affect the central nervous system via the olfactory bulb or blood circulation in many studies. In addition to causing anosmia or hyposmia, as well as taste disorders, the virus can also cause headaches, eye pain, ear pain, dizziness, and hallucination(63). The gonadotropin-releasing hormone receptor (GnRHRs), also known as the luteinizing hormone releasing hormone receptor (LHRHR), is a member of the seventransmembrane, G-protein coupled receptor (GPCRS) family(20). According to our findings, COVID-19 could bind to GnRHRs leading to blocking the binding of $\mathrm{GnRH}$ to this receptor and disrupts its signal resulting in hypogonadism and anosmia. It was found that congenital anosmia (inability to smell) is frequently associated with GnRH deficiency in humans, leading to the widely held belief that GnRH neurons rely on olfactory structures to reach the brain, but this hypothesis has yet to be proven. (21). The olfactory bulb (OB) is a conserved region found in brain that its main function is receiving sensory neurons direct synaptic input in the nasal epithelium part and conveys that instructions to the rest of the brain (22). It gets instructions from the brain regarding odours recognized by cells in the nasal cavity. Axons of the olfactory sensory neurons extends to the region of the olfactory bulb, which is dedicated to process odourrelated instructions (23).The nervus terminalis, or zeroeth cranial nerve, contains specific neurons that produce gonadotropin-releasing 
hormone (GnRH). All vertebrate animals without sharks have a nervus terminalis, a chain of neurons implanted within vomeronasal or olfactory nerves in the region of the nasal canal, where it is considered a distinct nerve. The main role of the gonadotropinreleasing hormone ( $\mathrm{GnRH}$ ) constituent of the nervus terminalis is supposed to have neuromodulatory properties . (24). Numerous studies suggested that the role of the intranasal gonadotropinreleasing hormone ( $\mathrm{GnRH}$ ) system is to adapt and modify olfactory information, maybe at opportune times for reproduction.(24) 30 to 40 percent of neurons located in the region of the nervus terminalis genetically express gonadotropin-releasing hormone ( $\mathrm{GnRH})$, and a small dozen of these neurons may produce gonadotropin-releasing hormone $(\mathrm{GnRH})$ directly into blood veins underlying the olfactory epithelium (OE). (25). During prenatal GnRH neurons emerge from the nasal placode and travel into the brain(26). These neurons become critical ingredients of the hypothalamic-pituitary-gonadal axis, which is required for activity of reproduction, after they enter the brain. Hypogonadotropic hypogonadism ( $\mathrm{HH}$ ) is caused when this mechanism is disrupted $(\mathrm{HH})$. Kallman syndrome is a clinical term for $\mathrm{HH}$ that is accompanied by anosmia (KS)(5). A. Maestre de San Juan in 1856, he was the first to describe a loss of smell and hypogonadism (a disorder in which the body produces insufficient amounts of a hormone). followed by F. J. Kallmann in 1944. $(26,27)$ Kallmann discovered a co-segregation of hypogonadism and anosmia (loss of smell) in 3 families and hypothesised that the disease, now known as Kallmann syndrome, was hereditary (KS) (27). Changes in sense of smell are potentially connected with Covid19, specifically in patients with fever symptoms and women , according to 17 research articles found in databases; these changes rise Covid-19, degree of suspicion, and they warrant the implementation of surveillance and isolation measures as soon as possible(28). Although no current research has looked at its function in host contagion, but dysosmia (disordered smell perception) which 
has been found in cases with covid-19 infection might recall disorders related to the sense of smell typical of the Kallmann syndrome(KS), where the terminal nerve may play an important role in disruption of hormones . Furthermore, a study showed that COVID-19 patients had considerably lower levels of total Testosterone (tT) and luteinizing hormone ( $\mathrm{LH}$ ) than control (p o.0001), while controls had lower levels of circulating Estradiol(E2). In 257 (89.8\%) of the hospitalized patients, testosterone levels suggestive of hypogonadism were detected (29).The hypothalamus is a critical region located in the brain that produces, integrates, and regulates several processes including the blood pressure, hormonal balance, body temperature, circadian rhythm, basal homeostasis, emotion and sexual behavior (30,31) . Through the circulating amounts of gonadal sex steroids and stress hormones, the hypothalamus is functionally connected to the pituitary gland, gonads and adrenal gland (32) The primary regulator of mammalian function of reproduction in both men and womens is gonadotropin-releasing hormone $(\mathrm{GnRH})$. It acts via distinct receptors, G-protein coupled receptors $(\mathrm{GnRH})$ found in gonadotropes to induce production of the gonadotropin hormones, follicle and luteinizing -stimulating hormones (FSH), (LH)(33).

\section{COVID-19 could block thyroxin GPCRSs leading to hypothyroidism and anosmia.}

There is an increasing body of literature on the impact of COVID-19 on the pituitary-thyroid axis. Currently, we know that SARS-CoV-2 could lead to short-term and reversible thyroid dysfunction. According to our findings, COVID-19 could bind to thyroxin GPCRSs leading to blocking the binding of thyroxin to this receptor and disrupt its signal resulting in hypothyroidism . The thyroid-stimulating hormone (TSH) or thyrotropin (34) receptor 
(TSHR) $(35,36)$ is a member of the class A G-protein-coupled receptors (GPCRSs) (37). It was revealed that a significant proportion of hypothyroidism associated with COVID-19 and altered thyroid hormones was significantly more in COVID-19 patients as compared to control groups(38) . It was showed that Hypothyroidism is associated with prolonged COVID-19-induced $\operatorname{anosmia(39)}$

\section{COVID-19 could block GPCRSs leading to disorder in tastes .}

According to the report of Moein et al., the publications included case reports or self-report surveys among different countries, and researchers proved the loss of smell and taste as a predictor of COVID-19 (40). Taste is one of the most important sensations for human life, enabling us to perceive different tastes from the diverse range of food available in nature and is a major determinant of our ingestion decisions(41). The anatomical units of taste detection are taste receptor cells (TRCs) that are assembled into taste buds distributed across different papillae of the tongue and palate epithelium. Taste processing is first achieved at the level of TRCs that are activated by specific tastants. They transmit information via sensory afferent fibers to the gustatory cortex in the brain for taste perception. Three different morphologic subtypes of TRCs in taste buds sense the different tastes we perceive. Type I gliallike cells detect salty taste while type II cells expressing GPCRSs detect sweet, umami, and bitter tastes. Type III cells sense sour stimuli $(41,42)$. Therefore, according to our findings COVID-19 could target GPCRSsin Type II cells leading to taste disorder 


\section{COVID-19 could bind to GPCRSs leading to blocking of GPCRS signaling and pulmonary edema}

COVID-19 mortality is primarily driven by abnormal alveolar fluid metabolism of the lung, leading to fluid accumulation in the alveolar airspace. This condition is generally referred to as pulmonary edema and is a direct consequence of severe acute respiratory syndrome coronavirus 2 (SARS-CoV-2) infection(43). GPCRSs are primarily responsible for signal transduction/propagation cascades $(44,45)$. GPCRSs located on the cell surface transduce exogenous signals that activate GTP-binding "G" proteins, which in turn activate effector proteins (such as adenylyl cyclase and phospholipases) and second messengers (such as calcium or cAMP) $(44,45)$. The cAMP/PKA pathway (46) regulates CFTR activity and is typically induced by Gs-coupled GPCRSs that stimulate adenylyl cyclase (AC), raising cAMP levels and stimulating PKA (47). Invading pathogens, on the other hand, frequently exploit these endogenous signalling pathways (48). $\searrow$ The A2B adenosine receptors and the 2 adrenergic receptors are two specific GPCRSs that are primarily involved in CFTR regulation and are abundantly expressed in the airways (47, 49). Under physiological conditions, the adenosine-CFTR regulation system is essential for mucosal airway surface protection (50) and alveolar surface layer (ASL) regulation (51). Viruses, on the other hand, are well known for their ability to not only use GPCRSs to enter host cells, but also to use their intracellular signalling pathways for survival and replication (48). Based on this general concept, it is possible that SARS-CoV-2 may also compromise GPCRS signalling, and this effect may contribute to the pathophysiology of pulmonary edema. 


\section{COVID-9 could disrupt progesterone signaling via binding to progesterone receptors (GPCR)}

The progesterone prepares the body for pregnancy in the event that the released egg is fertilized. If the egg is not fertilized, the corpus luteum breaks down, the production of progesterone falls and a new menstrual cycle begins. Membrane progesterone receptors (mPRa, mPR $\beta, \operatorname{mPR} \gamma, \mathrm{mPR} \delta$, and $\mathrm{mPR} \varepsilon$ ) were identified as putative $\mathrm{G}$ protein-coupled receptors (GPCRs) for progesterone(69). It was showed that female patients with COVID- 19 had various extents of transient menstrual changes, mainly manifesting as prolonged cycles and decreased volume. A few patients also showed shortened or disordered menstrual cycles and increased volume, which were rarely observed in the control group(70). Therefore, COVID-19 could disrupt progesterone signaling leading to menstrual cycle disturbance.

\section{COVID-9 could disrupt FSH signaling leading to low expression of Rbp4 and retinol deficiency.}

Follicle-stimulating hormone (FSH) is central to reproduction in mammals. It acts through a G-protein-coupled receptor on the surface of target cells to stimulate testicular and ovarian functions(71).It was showed that FSH increased the levels of total retinoids and retinal; and that FSH also stimulated the gene expression of STRA6 and CRBP1 (which are thought to play important roles in retinol uptake by cells(72,73). $\mathrm{ADH} 1$ and $\mathrm{ADH}_{7}$ (which catalyze the conversion of retinol to retinal (74), and ALDH1A1 (which catalyzes the conversion of retinal to RA (74). Therefore, FSH also enhances the uptake and metabolism of retinol in granulosa cells, though the increase in RA levels was not significant. The increase in retinyl ester levels may be caused by the quick uptake of retinol into cells under the stimulation of FSH, which 
may then result in the accumulation of retinyl esters. Another study showed that FSH can also increase retinyl ester levels in the presence of physiological concentration of retinol (i.e. $1 \mu \mathrm{M}$ ) in Sertoli cells cultured in vitro (75). The expression of Rbp4 was significantly induced by follicle-stimulating hormone ( $\mathrm{FSH})$ or $\mathrm{FSH}+$ luteinizing hormone (LH) in combination in immature mouse (3 weeks old) ovaries in vivo and in granulosa cells cultured in vitro, both at the mRNA and protein levels(76). Therefore,COVID-9 could inhibit Rbp4 and retinol enzyme activation leading to retinol deficiency via disrupting FSH signaling •

\section{COVID-19 could disrupt The ghrelin receptor a $G$ protein-coupled receptor (GPCR) in the brain leading to less appetite}

It was explore the associated factors of appetite and death anxiety amongst COVID-19 patients and found that COVID-19 patients suffered from Appetite loss. In comparison with other chronic diseases, the risk rate in patients diagnosed with COVID-19 was very high (77,78). The ghrelin receptor is a $G$ protein-coupled receptor (GPCR) mainly distributed in the brain, and also expressed in peripheral tissues. Remarkably, the ghrelin receptor possesses a naturally high constitutive activity representing 50\% of its maximal activity(79). Ghrelin is a newly discovered brain-gut peptide and an endogenous ligand for growth hormone secretagogues receptor (GHS-R). Ghrelin and GHS-R present extensively in central and peripheral tissues such as stomach, brain and other organs of rodent and human, which suggest it has multiple biological effects. It has been reported that ghrelin has significant role in the regulation of energy homeostasis, food intake and appetite(80). Levels of ghrelin circulation in the body fluctuate in response to the time elapsed since 
a person's last meal, falling immediately after food consumption. Grehlin receptors are in the brain (central area) and the vagus nerve leading to the stomach (periphery)(81) According to our results COVID-19 could bind to Grehlin GPCR receptors leading to disruption of its signal and Appetite loss which was showed among COVID-19 patients.

\section{COVID-19 could disrupt The Alpha-2- adrenergic receptors a G protein-coupled receptor (GPCR) in the brain leading to less High cortisol and Memory complication}

Alpha-2-adrenergic receptors are members of the $G$ proteincoupled receptor, The $\alpha 2$ adrenergic receptor (AR) belongs to the $\mathrm{G}$ protein-coupled receptor (GPCR) superfamily. In vivo, activation of the a2AR by endogenous ligand, epinephrine and norepinephrine, leads to decrease in epileptogenesis (82) and anxiety (83). In response to a2-agonists, the a2AR activation can lower blood pressure by central mechanisms $(84,85)$, evoke sedation $(85)$, reduce pain perception $(85,86)$, and improve working memory $(87,88)$. There are three subtypes of a2ARs, a2A-, $\alpha_{2} B-$ and $\alpha_{2} A A R$, which are encoded by three different genes but all couple to the Gi/o subfamily of $\mathrm{G}$ proteins to inhibit adenylyl cyclase and voltage-gated Ca2+ channels and to activate receptor-operated $\mathrm{K}+$ channels and mitogen-activated protein kinase (MAPK) in native cells $(89,90)$.

It was showed that The ADRA2A agonist clonidine enhanced both basal and stimulated cortisol production. Clonidine-induced increase in basal cortisol levels was blocked by the ADRA2A antagonist yohimbine(91). Here, we suggest that COVID-19 could bind to 
ADRA2A GPCRs and act as ADRA2A antagonist leading to increasing blood cortisol in COVID-19 patients.

\section{Conflicts of interest}

The authors have no conflicts of interest to declare that are relevant to the content of this article

\section{Funding}

None

\section{Acknowledgments}

Contains gratitude and appreciation for Egypt for providing the funds for this project and the parties involved in the research but not included in authorship.

\section{Reverences}

1- Deshpande DA, Wang WC, Mcllmoyle EL, Robinett KS, Schillinger RM, An SS, Sham JS, Liggett SB. Bitter taste receptors on airway smooth muscle bronchodilate by localized calcium signaling and reverse obstruction. Nat Med. 2010 Nov;16(11):1299-304. doi: 10.1038/nm.2237. Epub 2010 Oct 24. PMID: 20972434; PMCID: PMC3066567.

2- Billington, C. K., and Penn, R. B. (2003). Signaling and regulation of G protein-coupled receptors in airway smooth muscle. Respir. Res. 4, 2. doi:10.1186/1465-9921-4-2

3- Schoneberg, T., Schulz, A., Biebermann, H., Hermsdorf, T., Rompler, H., and Sangkuhl, K. (2004). Mutant G-protein-coupled receptors as a cause of human diseases. Pharmacol. Ther. 104 (3), 173-206. doi:10.1016/j.pharmthera.2004.08.008 
4- Lundstrom, K. (2009). An overview on GPCRSs and drug discovery: structure-based drug design and structural biology on GPCRSs. Methods Mol. Biol. 552, 51-66. doi:10.1007/978-160327-317-6_4

5- Lagerström, M. C., and Schiöth, H. B. (2008). Structural diversity of G protein-coupled receptors and significance for drug discovery. Nat. Rev. Drug Discov. 7 (4), 339-357. doi: $10.1038 / \mathrm{nrd} 2518$

6- Rosenbaum, D. M., Rasmussen, S. G. F., and Kobilka, B. K. (2009). The structure and function of G-protein-coupled receptors. Nature 459 (7245), 356-363. doi:10.1038/nature08144

7- Venkatakrishnan, A. J., Deupi, X., Lebon, G., Tate, C. G., Schertler, G. F., and Babu, M. M. (2013). Molecular signatures of G-protein-coupled receptors. Nature 494, 185. doi:10.1038/nature11896

8- Ahmad, R., Wojciech, S., and Jockers, R. (2015). Hunting for the function of orphan GPCRSs - beyond the search for the endogenous ligand. Br. J. Pharmacol. 172 (13), 3212-3228. doi:10.1111/bph.12942

9- Anwar MM, Badawi AM, Eltablawy NA. Can the coronavirus infection penetrates the brain resulting in sudden anosmia followed by severe neurological disorders? eNeurologicalSci. 2020 Dec;21:100290. doi: 10.1016/j.ensci.2020.100290. Epub 2020 Nov 11. PMID: 33200104; PMCID: PMC7657010.

10- de Melo GD, Lazarini F, Levallois S, Hautefort C, Michel V, Larrous F, Verillaud B, Aparicio C, Wagner S, Gheusi G, Kergoat L, Kornobis E, Donati F, Cokelaer T, Hervochon R, Madec Y, Roze E, Salmon D, Bourhy H, Lecuit M, Lledo PM. COVID-19-related anosmia is associated with viral persistence and inflammation in human olfactory epithelium and brain infection in hamsters. Sci Transl Med. 2021 Jun 2;13(596):eabf8396. doi: 10.1126/scitranslmed.abf8396. Epub 2021 May 3. PMID: 33941622; PMCID: PMC8158965.

11- Briguglio, M., Bona, A., Porta, M., Dell'Osso, B., Pregliasco, F. E., and Banfi, G. (2020). Disentangling the hypothesis of host dysosmia and SARS-CoV-2: the bait symptom that hides neglected neurophysiological routes. Front. Physiol. 11:671. doi: 10.3389/fphys.2020.00671 12 -Butowt, R., and Bilinska, K. (2020). SARS-CoV-2: olfaction, brain infection, and the urgent need for clinical samples allowing earlier virus detection. ACS Chem. Neurosci. 11, 1200-1203. doi: 10.1021/acschemneuro.0c00172

13-Li, Z., Liu, T., Yang, N., Han, D., Mi, X., Li, Y., et al. (2020). Neurological manifestations of patients with COVID-19: potential routes of SARS-CoV-2 neuroinvasion from the periphery to the brain. Front. Med. 14:533-541. doi: 10.1007/s11684-020-0786-5

14 -Meinhardt, J., Radke, J., Dittmayer, C., Franz, J., Thomas, C., Mothes, R., et al. (2021). Olfactory transmucosal SARS-CoV-2 invasion as a port of central nervous system entry in individuals with COVID-19. Nat. Neurosci. 24, 168-175. doi: 10.1038/s41593-020-00758-5

15- Butowt, R., and von Bartheld, C. S. (2020). Anosmia in COVID-19: underlying mechanisms and assessment of an olfactory route to brain infection. Neuroscientist doi: 10.1177/1073858420956905 Epub ahead of print. 
16- Cooper, K. W., Brann, D. H., Farruggia, M. C., Bhutani, S., Pellegrino, R., Tsukahara, T., et al. (2020). COVID-19 and the chemical senses: supporting players take center stage. Neuron 107, 219-233. doi: 10.1016/j.neuron.2020.06.032.

17- Brechbühl, J., Wood, D., Bouteiller, S., Lopes, A. C., Verdumo, C., and Broillet, M.-C. (2021). Age-dependent appearance of SARS-CoV-2 entry cells in mouse chemosensory systems reflects COVID-19 anosmia and ageusia symptoms. bioRxiv [Preprint]. Available Online at: https://doi.org/10.1101/2021.03.29.437530 (accessed May 30, 2021).

18- Butowt, R., Meunier, N., Bryche, B., and von Bartheld, C. S. (2021). The olfactory nerve is not a likely route to brain infection in COVID-19: a critical review of data from humans and animal models. Acta Neuropathol. 141, 809-822.

19 - Gori, A., Leone, F., Loffredo, L., Cinicola, B. L., Brindisi, G., De Castro, G., Spalice, A., Duse, M., \& Zicari, A. M. (2020). COVID-19-Related Anosmia: The Olfactory Pathway Hypothesis and Early Intervention. Frontiers in neurology, 11, 956. https://doi.org/10.3389/fneur.2020.00956

20- Perrett, Rebecca M, and Craig A McArdle. "Molecular mechanisms of gonadotropinreleasing hormone signaling: integrating cyclic nucleotides into the network." Frontiers in endocrinology vol. 4 180. 20 Nov. 2013, doi:10.3389/fendo.2013.00180

21- Angela Delaney, Rita Volochayev, Brooke Meader, Janice Lee, Konstantinia Almpani, Germaine Y Noukelak, Jennifer Henkind, Laura Chalmers, Jennifer R Law, Kathleen A Williamson, Christina M Jacobsen, Tatiana Pineda Buitrago, Orlando Perez, Chie-Hee Cho, Angela Kaindl, Anita Rauch, Katharina Steindl, Jose Elias Garcia, Bianca E Russell, Rameshwar Prasad, Uttam K Mondal, Hallvard M Reigstad, Scott Clements, Susan Kim, Kaoru Inoue, Gazal Arora, Kathryn B Salnikov, Nicole P DiOrio, Rolando Prada, Yline Capri, Kosuke Morioka, Michiyo Mizota, Roseli M Zechi-Ceide, Nancy M Kokitsu-Nakata, Cristiano Tonello, Siulan Vendramini-Pittoli, Gisele da Silva Dalben, Ravikumar Balasubramanian, Andrew A Dwyer, Stephanie B Seminara, William F Crowley, Jr, Lacey Plummer, Janet E Hall, John M Graham, Jr, Angela E Lin, Natalie D Shaw, Insight Into the Ontogeny of GnRH Neurons From Patients Born Without a Nose, The Journal of Clinical Endocrinology \& Metabolism, Volume 105, Issue 5 , May 2020, Pages 1538-1551, https://doi.org/10.1210/clinem/dgaa065

22-McGann, John P. "Poor human olfaction is a 19th-century myth." Science (New York, N.Y.) vol. 356,6338 (2017): eaam7263. doi:10.1126/science.aam7263

23-Nagayama S, Homma R, Imamura F. Neuronal organization of olfactory bulb circuits. Front Neural Circuits. 2014 Sep 3;8:98. doi: 10.3389/fncir.2014.00098. PMID: 25232305; PMCID: PMC4153298.

24-Wirsig-Wiechmann CR. Function of gonadotropin-releasing hormone in olfaction. Keio J Med. 2001 Jun;50(2):81-5. doi: 10.2302/kjm.50.81. PMID: 11450596.

25 -Bilinska K, von Bartheld CS, Butowt R. Expression of the ACE2 virus entry protein in the nervus terminalis reveals the potential for an alternative route to brain infection in COVID-19. bioRxiv [Preprint]. 2021 Jun 7:2021.04.11.439398. doi: 10.1101/2021.04.11.439398. Update in: Front Cell Neurosci. 2021 Jul 05;15:674123. PMID: 33880469; PMCID: PMC8057234. 
26-Forni, Paolo E, and Susan Wray. "GnRH, anosmia and hypogonadotropic hypogonadism-where are we?." Frontiers in neuroendocrinology vol. 36 (2015): 165-77. doi:10.1016/j.yfrne.2014.09.004

27- Kallmann FJ BS. The genetic aspects of primary eunuchoidism. J Ment Defic. 1944;48:203236

28- da Silva Júnior PR, Gomes ALOR, Coelho LEA, Morais MA, de Almeida PVFC, Neri WJR, Mascena GV, de Farias Leal AA. Anosmia and COVID-19: perspectives on its association and the pathophysiological mechanisms involved. Egypt J Neurol Psychiatr Neurosurg. 2021;57(1):8. doi: 10.1186/s41983-020-00266-0. Epub 2021 Jan 7. PMID: 33437144; PMCID: PMC7790051.

29- Salonia A, Pontillo M, Capogrosso P, Gregori S, Tassara M, Boeri L, Carenzi C, Abbate C, Cignoli D, Ferrara AM, Cazzaniga W, Rowe I, Ramirez GA, Tresoldi C, Mushtaq J, Locatelli M, Santoleri L, Castagna A, Zangrillo A, De Cobelli F, Tresoldi M, Landoni G, Rovere-Querini P, Ciceri F, Montorsi F. Severely low testosterone in males with COVID-19: A case-control study. Andrology. 2021 Jul;9(4):1043-1052. doi: 10.1111/andr.12993. Epub 2021 Mar 9. PMID: 33635589; PMCID: PMC8013327.

30- Fassbender K, Schmidt R, Mössner R, Kischka U, Kühnen J, Schwartz A, Hennerici M. Mood disorders and dysfunction of the hypothalamic-pituitary-adrenal axis in multiple sclerosis: association with cerebral inflammation. Arch Neurol. 1998 Jan;55(1):66-72. doi: 10.1001/archneur.55.1.66. PMID: 9443712.

31- Guijarro A, Laviano A, Meguid MM. Hypothalamic integration of immune function and metabolism. Prog Brain Res. 2006;153:367-405. doi: 10.1016/S0079-6123(06)53022-5. PMID: 16876587; PMCID: PMC7119041.

32-Kandasamy M, Radhakrishnan RK, Poornimai Abirami GP, Roshan SA, Yesudhas A, Balamuthu K, Prahalathan C, Shanmugaapriya S, Moorthy A, Essa MM, Anusuyadevi M. Possible Existence of the Hypothalamic-Pituitary-Hippocampal (HPH) Axis: A Reciprocal Relationship Between Hippocampal Specific Neuroestradiol Synthesis and Neuroblastosis in Ageing Brains with Special Reference to Menopause and Neurocognitive Disorders. Neurochem Res. 2019 Aug;44(8):1781-1795. doi: 10.1007/s11064-019-02833-1. Epub 2019 Jun 28. PMID: 31254250.

33-Perrett, R. M., \& McArdle, C. A. (2013). Molecular mechanisms of gonadotropin-releasing hormone signaling: integrating cyclic nucleotides into the network. Frontiers in endocrinology, 4, 180. https://doi.org/10.3389/fendo.2013.00180

34- Mussett MV, Perry WL. The international standard for thyrotrophin. Bull World Health Organ (1955) 13:917-29.

35- Libert F, Lefort A, Gerard C, Parmentier M, Perret J, Ludgate M, et al. Cloning, sequencing and expression of the human thyrotropin (TSH) receptor: evidence for binding of autoantibodies. Biochem Biophys Res Commun (1989) 165:1250-5. doi:10.1016/0006291X(89)92736-8

36- Misrahi M, Loosfelt $H$, Atger M, Sar S, Guiochon-Mantel A, Milgrom E. Cloning, sequencing and expression of human TSH receptor. Biochem Biophys Res Commun (1990) 166:394-403. doi:10.1016/0006-291X(90)91958-U. 
37- The G-protein-coupled receptors in the human genome form five main families. Phylogenetic analysis, paralogon groups, and fingerprints. Fredriksson $R$, Lagerström $M C$, Lundin LG, Schiöth HB Mol Pharmacol. 2003 Jun; 63(6):1256-72.

38- Malik J, Zaidi SMJ, Waqar AU, Khawaja H, Malik A, Ishaq U, Rana AS, Awan AH. Association of hypothyroidism with acute COVID-19: a systematic review. Expert Rev Endocrinol Metab. 2021 Sep;16(5):251-257. doi: 10.1080/17446651.2021.1968830. Epub 2021 Aug 23. PMID: 34424110 .

39-Tsivgoulis G, Fragkou PC, Karofylakis E, Paneta M, Papathanasiou K, Palaiodimou L, Psarros C, Papathanasiou M, Lachanis S, Sfikakis PP, Tsiodras S. Hypothyroidism is associated with prolonged COVID-19-induced anosmia: a case-control study. J Neurol Neurosurg Psychiatry. 2021 Apr 20:jnnp-2021-326587. doi: 10.1136/jnnp-2021-326587. Epub ahead of print. PMID: 33879534.

40- S.T. Moein, S.M. Hashemian, B. Mansourafshar, A. Khorram - Tousi, P. Tabarsi, R.L. Doty Smell dysfunction: a biomarker for COVID-19 Int Forum Allergy Rhinol, 10 (8) (2020), pp. 944950

41- Ahmad R, Dalziel JE. G Protein-Coupled Receptors in Taste Physiology and Pharmacology. Front Pharmacol. 2020 Nov 30;11:587664. doi: 10.3389/fphar.2020.587664. PMID: 33390961; PMCID: PMC7774309.

42- Janssen, S., and Depoortere, I. (2013). Nutrient sensing in the gut: new roads to therapeutics? Trends Endocrinol Metab 24 (2), 92-100. doi:10.1016/j.tem.2012.11.006

43- Cui X, Chen W, Zhou H, Gong Y, Zhu B, Lv X, Guo H, Duan J, Zhou J, Marcon E, Ma H. Pulmonary Edema in COVID-19 Patients: Mechanisms and Treatment Potential. Front Pharmacol. 2021 Jun 7;12:664349. doi: 10.3389/fphar.2021.664349. PMID: 34163357; PMCID: PMC8215379.

44- Review Structure-function of the $G$ protein-coupled receptor superfamily. Katritch $V$, Cherezov V, Stevens RC Annu Rev Pharmacol Toxicol. 2013; 53():531-56.

45- Review Regulation of GPCRS activity, trafficking and localization by GPCRS-interacting proteins. Magalhaes AC, Dunn H, Ferguson SS Br J Pharmacol. 2012 Mar; 165(6):1717-1736

46- Review Local modulation of cystic fibrosis conductance regulator: cytoskeleton and compartmentalized cAMP signalling. Monterisi S, Casavola V, Zaccolo M Br J Pharmacol. 2013 May; 169(1):1-9.

47- Activation of airway $\mathrm{cl}$ - secretion in human subjects by adenosine. Hentchel-Franks K, Lozano D, Eubanks-Tarn V, Cobb B, Fan L, Oster R, Sorscher E, Clancy JP Am J Respir Cell Mol Biol. 2004 Aug; 31(2):140-6.

48-Review Viral hijacking of G-protein-coupled-receptor signalling networks Sodhi A, Montaner S, Gutkind JS Nat Rev Mol Cell Biol. 2004 Dec; 5(12):998-1012.

49- A macromolecular complex of beta 2 adrenergic receptor, CFTR, and ezrin/radixin/moesin-binding phosphoprotein 50 is regulated by PKA. Naren AP, Cobb B, Li C, Roy K, Nelson D, Heda GD, Liao J, Kirk KL, Sorscher EJ, Hanrahan J, Clancy JP Proc Natl Acad Sci U S A. 2003 Jan 7; 100(1):342-6. 
50- The Cystic Fibrosis Transmembrane Conductance Regulator (CFTR) Uses its C-Terminus to Regulate the A2B Adenosine Receptor. Watson MJ, Lee SL, Marklew AJ, Gilmore RC, Gentzsch M, Sassano MF, Gray MA, Tarran R Sci Rep. 2016 Jun 9; 6():27390.

51- Adenosine regulation of cystic fibrosis transmembrane conductance regulator through prostenoids in airway epithelia. Li Y, Wang W, Parker W, Clancy JP Am J Respir Cell Mol Biol. 2006 May; 34(5):600-8.

52- Vassilatis, Demetrios K et al. "The G protein-coupled receptor repertoires of human and mouse." Proceedings of the National Academy of Sciences of the United States of America vol. 100,8 (2003): 4903-8. doi:10.1073/pnas.0230374100

53- Spehr, Marc, and Steven D Munger. "Olfactory receptors: G protein-coupled receptors and beyond." Journal of neurochemistry vol. 109,6 (2009): 1570-83. doi:10.1111/j.14714159.2009.06085.x

54- A novel multigene family may encode odorant receptors: a molecular basis for odor 54 recognition. Buck L, Axel R Cell. 1991 Apr 5; 65(1):175-87.

55- The good taste of genomics. Firestein S Nature. 2000 Apr 6; 404(6778):552-3.

56- Review Orphan G-protein-coupled receptors and natural ligand discovery. Howard AD, McAllister G, Feighner SD, Liu Q, Nargund RP, Van der Ploeg LH, Patchett AA Trends Pharmacol Sci. 2001 Mar; 22(3):132-40.

57- Review Orphan G protein-coupled receptors in the CNS. Lee DK, George SR, Evans JF, Lynch KR, O'Dowd BF Curr Opin Pharmacol. 2001 Feb; 1(1):31-9.

58- Hentchel-Franks K, Lozano D, Eubanks-Tarn V, Cobb B, Fan L, Oster R, Sorscher E, Clancy JP. Activation of airway cl- secretion in human subjects by adenosine. Am J Respir Cell Mol Biol 31: 140-146, 2004. doi:10.1165/rcmb.2004-00120C.

59 - Naren AP, Cobb B, Li C, Roy K, Nelson D, Heda GD, Liao J, Kirk KL, Sorscher EJ, Hanrahan J, Clancy JP. A macromolecular complex of beta 2 adrenergic receptor, CFTR, and ezrin/radixin/moesin-binding phosphoprotein 50 is regulated by PKA. Proc Natl Acad Sci USA 100: 342-346, 2003. doi:10.1073/pnas. 0135434100

60- Watson MJ, Lee SL, Marklew AJ, Gilmore RC, Gentzsch M, Sassano MF, Gray MA, Tarran $\mathrm{R}$. The cystic fibrosis transmembrane conductance regulator (CFTR) uses its C-terminus to regulate the A2B adenosine receptor. Sci Rep 6: 27390, 2016. doi:10.1038/srep27390.

61- Li Y, Wang W, Parker W, Clancy JP. Adenosine regulation of cystic fibrosis transmembrane conductance regulator through prostenoids in airway epithelia. Am J Respir Cell Mol Biol 34: 600-608, 2006. doi:10.1165/rcmb.2005-04210C.

62- Sodhi A, Montaner S, Gutkind JS. Viral hijacking of G-protein-coupled-receptor signalling networks. Nat Rev Mol Cell Biol 5: 998-1012, 2004. doi:10.1038/nrm1529.

63- J. Mirza, A. Ganguly, A. Ostrovskaya, A. Tusher, R. Viswanathan Command suicidal hallucination as initial presentation of coronavirus disease 2019 (COVID-19): a case report Psychosomatics, 61 (5) (2020), pp. 561-564 
64- M. L. Connolly, "Solvent-accessible surfaces of proteins and nucleic acids," Science, vol. 221, no. 4612, pp. 709-713, 1983.

65- M. L. Connolly, "Analytical molecular surface calculation," Journal of Applied Crystallography, vol. 16, pp. 548-558, 1983.

66- C. Zhang, G. Vasmatzis, J. L. Cornette, and C. DeLisi, "Determination of atomic desolvation energies from the structures of crystallized proteins," Journal of Molecular Biology, vol. 267, no. 3, pp. 707-726, 1997.

67- Jiang, Y., Zhao, Y., Chen, S. et al. Regulation by FSH of the dynamic expression of retinolbinding protein 4 in the mouse ovary. Reprod Biol Endocrinol 16, 25 (2018). https://doi.org/10.1186/s12958-018-0348-8

68- Li K, Chen G, Hou H, et al. Analysis of sex hormones and menstruation in COVID-19 women of child-bearing age. Reprod Biomed Online 2021;42(1):260-67. doi: 10.1016/j.rbmo.2020.09.020 [published Online First: 2020/12/09]

69- Warren MP, Siris ES, Petrovich C. The influence of severe illness on gonadotropin secretion in the postmenopausal female. Journal of Clinical Endocrinology and Metabolism 1977;45:99-104.

69- Kasubuchi, M., Watanabe, K., Hirano, K. et al. Membrane progesterone receptor beta (mPRß/Paqr8) promotes progesterone-dependent neurite outgrowth in PC12 neuronal cells via non-G protein-coupled receptor (GPCR) signaling. Sci Rep 7, 5168 (2017). https://doi.org/10.1038/s41598-017-05423-9

70- Li, K., Chen, G., Hou, H., Liao, Q., Chen, J., Bai, H., Lee, S., Wang, C., Li, H., Cheng, L., \& Ai, J. (2021). Analysis of sex hormones and menstruation in COVID-19 women of child-bearing age. Reproductive biomedicine online, 42(1), 260-267. https://doi.org/10.1016/j.rbmo.2020.09.020

71- Fan, Q. R., \& Hendrickson, W. A. (2005). Structure of human follicle-stimulating hormone in complex with its receptor. Nature, 433(7023), 269-277. https://doi.org/10.1038/nature03206

72- A membrane receptor for retinol binding protein mediates cellular uptake of vitamin A. Kawaguchi R, Yu J, Honda J, Hu J, Whitelegge J, Ping P, Wiita P, Bok D, Sun H Science. 2007 Feb 9; 315(5813):820-5.

73- Retinyl ester formation by lecithin: retinol acyltransferase is a key regulator of retinoid homeostasis in mouse embryogenesis.Kim YK, Wassef L, Hamberger L, Piantedosi R, Palczewski K, Blaner WS, Quadro LJ Biol Chem. 2008 Feb 29; 283(9):5611-21.

74- Review Potential role of retinoids in ovarian physiology and pathogenesis of polycystic ovary syndrome.Jiang Y, Li C, Chen L, Wang F, Zhou XClin Chim Acta. 2017 Jun; 469():87-93.

75- Follicle-stimulating hormone and leukemia inhibitory factor regulate Sertoli cell retinol metabolism.Guo X, Morris P, Gudas LEndocrinology. 2001 Mar; 142(3):1024-32. 
76- Kasubuchi, M., Watanabe, K., Hirano, K. et al. Membrane progesterone receptor beta (mPRB/Paqr8) promotes progesterone-dependent neurite outgrowth in PC12 neuronal cells via non-G protein-coupled receptor (GPCR) signaling. Sci Rep 7, 5168 (2017). https://doi.org/10.1038/s41598-017-05423-9

77-Zeng Q, Cao H, Ma Q, Chen J, Shi H, Li J. Appetite loss, death anxiety and medical coping modes in COVID-19 patients: a cross-sectional study. Nurs Open. 2021 Nov;8(6):3242-3250. doi: 10.1002/nop2.1037. Epub 2021 Aug 31. PMID: 34463433; PMCID: PMC8510753.

78-Høier, Alexander Teymour Zadeh Baboli et al. "Possibilities for Maintaining Appetite in Recovering COVID-19 Patients." Foods (Basel, Switzerland) vol. 10,2 464. 20 Feb. 2021, doi:10.3390/foods10020464

Liu, H., Sun, D., Myasnikov, A. et al. Structural basis of human ghrelin receptor signaling by ghrelin and the synthetic agonist ibutamoren. Nat Commun 12,6410 (2021). https://doi.org/10.1038/s41467-021-26735-5

80- Hou Z, Miao Y, Gao L, Pan H, Zhu S. Ghrelin-containing neuron in cerebral cortex and hypothalamus linked with the DVC of brainstem in rat. Regul Pept. 2006 May 15;134(2-3):12631. doi: 10.1016/j.regpep.2006.02.005. Epub 2006 Mar 6. PMID: 16600402

81- Ahima, R. S., \& Antwi, D. A. (2008). Brain regulation of appetite and satiety. Endocrinology and metabolism clinics of North America, 37(4), 811-823. https://doi.org/10.1016/j.ecl.2008.08.005

82- Schramm NL, McDonald MP, Limbird LE. The alpha(2a)-adrenergic receptor plays a protective role in mouse behavioral models of depression and anxiety. J Neurosci. 2001;21:4875-4882.

83-MacMillan LB, Hein L, Smith MS, Piascik MT, Limbird LE. Central hypotensive effects of the alpha2a-adrenergic receptor subtype. Science. 1996;273:801-3.

84-. Altman JD, Trendelenburg AU, MacMillan L, Bernstein D, Limbird L, Starke K, Kobilka BK, Hein L. Abnormal regulation of the sympathetic nervous system in alpha2A- adrenergic receptor knockout mice. Mol Pharmacol. 1999;56:154-161.

85- Lakhlani PP, MacMillan LB, Guo TZ, McCool BA, Lovinger DM, Maze M, Limbird LE. Substitution of a mutant alpha2a-adrenergic receptor via "hit and run"; gene targeting reveals the role of this subtype in sedative, analgesic, and anesthetic-sparing responses in vivo. Proc Natl Acad Sci U S A. 1997;94:9950-5.

86- Stone LS, MacMillan LB, Kitto KF, Limbird LE, Wilcox GL. The alpha2a adrenergic receptor subtype mediates spinal analgesia evoked by alpha2 agonists and is necessary for spinal adrenergic-opioid synergy. J Neurosci. 1997;17:7157-7165.

87-Franowicz JS, Kessler LE, Borja CM, Kobilka BK, Limbird LE, Arnsten AF. Mutation of the alpha2A-adrenoceptor impairs working memory performance and annuls cognitive enhancement by guanfacine. J Neurosci. 2002;22:8771-8777. 
88-Ma D, Zerangue N, Lin YF, Collins A, Yu M, Jan YN, Jan LY. Role of ER export signals in controlling surface potassium channel numbers. Science. 2001;291:316-9.

89.Marrs W, Kuperman J, Avedian T, Roth RH, Jentsch JD. Alpha-2 adrenoceptor activation inhibits phencyclidine-induced deficits of spatial working memory in rats. Neuropsychopharmacology. 2005;30:1500-1510.

90. Limbird LE. Receptors linked to inhibition of adenylate cyclase: additional signaling mechanisms. FASEB J. 1988;2:2686-2695.

91-Assie G, Louiset E, Sturm N, René-Corail F, Groussin L, Bertherat J, Thomas M, Lefebvre H, Feige JJ, Clauser E, Chabre O, Cherradi N. Systematic analysis of G protein-coupled receptor gene expression in adrenocorticotropin-independent macronodular adrenocortical hyperplasia identifies novel targets for pharmacological control of adrenal Cushing's syndrome. J Clin Endocrinol Metab. 2010 Oct;95(10):E253-62. doi: 10.1210/jc.2009-2281. Epub 2010 Jul 21. PMID: 20660048. 